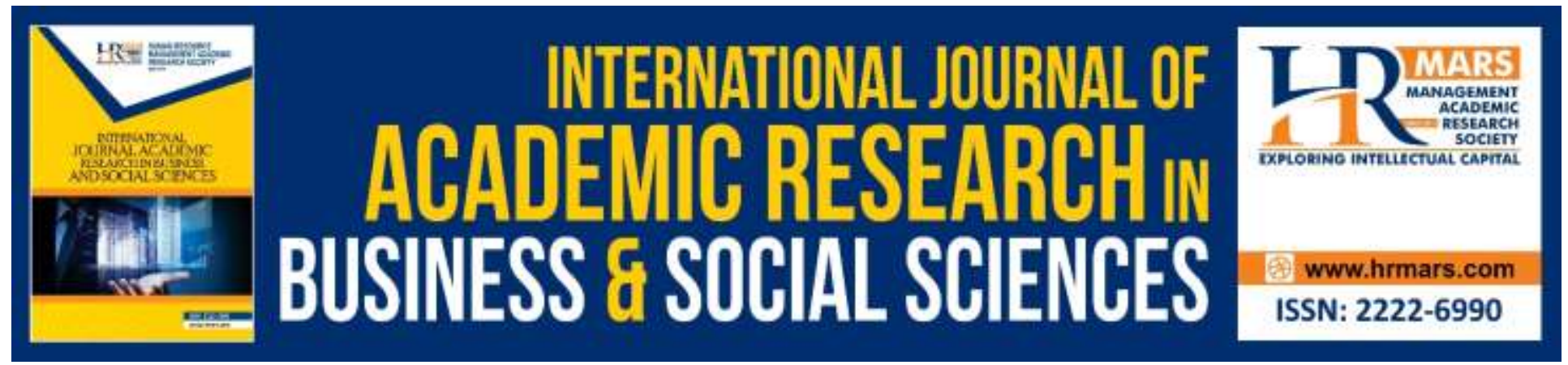

\title{
Allotment of Inheritance Mapping Research Using Geography Information System (GIS) In Setiu
}

Mohd Ali Mohd Yusuf, Roslan Umar, Ahmad Syakir Hadi Mat Tabiee

To Link this Article: http://dx.doi.org/10.6007/IJARBSS/v9-i11/6595

DOI: 10.6007/IJARBSS/v9-i11/6595

Received: 03 October 2019, Revised: 27 October 2019, Accepted: 07 November 2019

Published Online: 19 November 2019

In-Text Citation: (Yusuf, Umar, Tabiee, 2019)

To Cite this Article: Yusuf, M. A. M., Umar, R., Tabiee, A. S. H. M. (2019). Allotment of Inheritance Mapping Research Using Geography Information System (GIS) In Setiu. International Journal of Academic Research in Business and Social Sciences, 9(11), 741-753.

\section{Copyright: (C) 2019 The Author(s)}

Published by Human Resource Management Academic Research Society (www.hrmars.com)

This article is published under the Creative Commons Attribution (CC BY 4.0) license. Anyone may reproduce, distribute, translate and create derivative works of this article (for both commercial and non-commercial purposes), subject to full attribution to the original publication and authors. The full terms of this license may be seen at: $\underline{\text { http://creativecommons.org/licences/by/4.0/legalcode }}$

Vol. 9, No. 11, 2019, Pg. 741 - 753

Full Terms \& Conditions of access and use can be found at http://hrmars.com/index.php/pages/detail/publication-ethics 


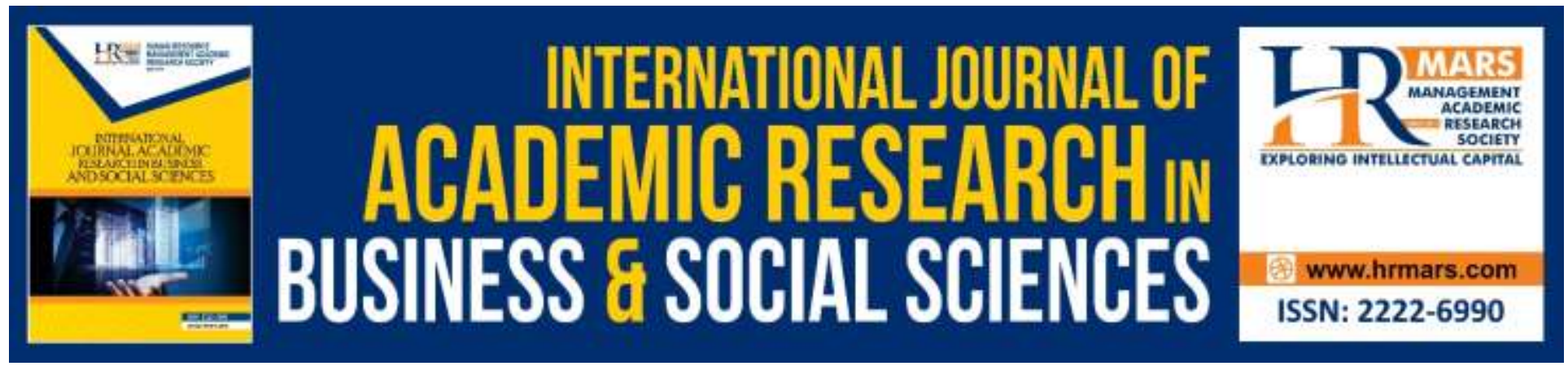

\title{
Allotment of Inheritance Mapping Research Using Geography Information System (GIS) In Setiu
}

\author{
Mohd Ali Mohd Yusuf, Roslan Umar, Ahmad Syakir Hadi Mat \\ Tabiee
}

Faculty of Islamic Contemporary Studies, Universiti Sultan Zainal Abidin

\begin{abstract}
Islam has fixed the method of Muslims inheritance allotment through ' 'faraid'.Nevertheless beneficiaries can still choose to divide the inheritance through agreement, sulh, takhruj, after explaining about the portion according to faraid. This relaxation is given due to the fact that there is a benefit to the beneficiaries in managing the distribution of the inheritance. This research is aimed to look at the trend of allotment of inheritance among Muslim community in Setiu, Terengganu, using Geography Information System (GIS) software. It is implemented using the qualitative method by collecting data that has been recorded in Syariah Subordinate Court Setiu in 2013. Data that had be collected was analyzed using Geography Information System Software for the allotment of inheritance mapping pattern in Setiu. It was found from the research that the majority of the Muslim community choose Faraid method to distribute their inheritance. The trend of such choice coincidence with the location of the research made in Syariah Subordinate Court in Setiu, Terengganu as it has been a reference by the people to choose faraid certificate. This research was successfully prove the effectiveness of the use of GIS in mapping the trend of managing the Muslim's inheritance in Setiu Terengganu.
\end{abstract}

Keywords: Educational Thought, Islamic Mathematics, KH. Fahmi Basya, Muslim Scholar, Holistic Education.

\section{Introduction}

According to al-Khin (1992) Islamic inheritance System implementation (monitoring) is aimed to strengthen family relationship among the beneficiaries. With that, Allah S.W.T has explained the basic of the law of inheritance through its implementation in Al-Quran and Hadith in depth (Awang, 2008). Muslims community has accepted this implementation as a method of inheritance allotment of those who demise to the beneficiary ever since. Even there are Islamic Scholar, of the opinion that the Muslims are required to implement such method in the allotment of the inheritance so as to show their compliance and obedience towards Allah S.W.T (al-Khin, 
1992). This discussion is included in the matter related to Islamic family law. This is due to the fact that the allotment of inheritance after the death of an individual to the heirs who have the night based on marriage relationship and descent.

Nevertheless, it is undeniable that there is certain situation that is easier for the heirs to manage the inheritance by using the other distribution method like 'agreement'. Especially in this modern era, whereby the belonging of certain wealth is bound with the registration of property law. Based on the needs for the heir, at the same time appreciating maqasid or the actual need of syura in the allotment of inheritance, so the other method of distribution is approved with certain requirements (Affanah, 2019; Yahya, Razali, \& Baki, 2018). These two methods of allotment of inheritance is implemented in the management of Muslim's inheritance in Malaysia. This has been specified in guidelines of distribution of small inheritance from small distribution section, Jabatan Ketua Pengarah Tanah dan Galian (JKPTG) to explain the provision Pusaka Kecil (Pembahagian) Act 1955 or 98 Act.

Therefore, Muslims can choose any suitable method to allocate inheritance without putting aside the Islamic inheritance law. The tendency of Muslim to choose the method of distribution of inheritance worth investigating. It is capable to be done in detail through the advancement of modern mapping technology using the Geography Information System. The pattern and trend that has been generated can be used to see its relationship with social structure and population demographics deeper. Based on those reasons, this research is done to map the inheritance allotment method using GIS software in Setiu district, Terengganu. This has been a new initiative in explaining issues related to allotment of inheritance using animation, drawing, scatches and shapes of map to simplify general understanding. The use of GIS software has been done a lot in science researches however this GIS effort has been a pilot project to see its effectiveness in mapping the method of distribution of inheritance among the Muslims in Setiu.

\section{The Meaning of Inheritance in Islam}

Inheritance in general is known as wealth that is left, therefore according to Dewan Dictionary, inheritance is all wealth that is left after somebody died (Baharom, 2010; Imam, Ali, Soo, 2018). The word inheritance with the above meaning in Arabic is called 'tarikah' or 'tirkah' which means something that is left behind. The law of Islamic inheritance and the method of allotting it is one of the debate in fiqah or Islamic Law, and is known as faraid. The word faraid is denoted from Arabic language showing the meaning of several (more than one), whereby in singular it means al-faridah which means al-mafrudah or something that is compulsory or the portion that has been stated.

Al-Sharbiny (1995) stated that, it is named faraid because it covers six elements as follows: a certain rate assigned section, gift to the heir explained from Allah s.w.t rate per beneficiary, what is legalized in the law. Besides, from the angle of syarak, the word faraid means the rate that is prescribed by Islamic Law to the heir. According to al-Asqalani (1987) inheritance is specified (al- 
mawarith) with the title faraid based on the saying of Allah in surah an-Nisa which means the part that is obligatory (mafruda) meaning what is stated, known and has been decided. While alKhin (1992) stated that al-Fard is the allotment that has specified rate by syarak, does not rise except with rad and does not reduce by aul.

Based on the above explaination, the definition of inheritance in Islam covers only faraid. This has been accepted and agreed by fikah scholars due to the discussion about will instrument, wakaf and grants being discussed in different chapters with faraid in their writings. Apart from using the faraid term, scholars also used the other terms like al-Mirath or al-Mawarith, referring to Islamic knowledge. According to al-Sabuni (1989), al-Mirath is wealth that is inherited by heir who is entitled to receive when someone in the family dies. According to faraid, the deceased's property should be used to settle his debt on that wealth, corpse handling, to settle his debts to anybody, will, wakaf that has been decided but unable to accomplish.

Integrating the mathematical concept with Islamic values is very important to be applied as a way of forming a nation's character (Samsul, 2015). Thus, it is necessary to develop continuously the analysis of mathematical material by associating the verses contained in the Qur'an which is the source of all the sources of knowledge that can be taken lessons and lessons by every human being through mathematics.

\section{Method of Allotment on Inheritance among Muslim Community in Malaysia}

According to section 12 (7) and section 13 (1) small Inheritance Act (Allotment) 1955, Muslim small inheritance can be divided according to faraid through agreement in discussion. Allotment of inheritance through faraid in this country is based on Shafie section. The portion that heir receives through faraid has been set by Allah s.w.t is divided to entitled heir after the death of one of family members. This is based on the proposition in Al-Quran in surah An Nisa, as explained by the prophet (p.b.u.h) through his hadith, ijtihad of his companions and the consensus from the scholars. The transition property of the deceased to his heirs is set to be done so, either the heirs accept or reject it. The allotment through faraid is compulsory according to Islamic scholars because this allotment has been decided by Allah s.w.t in the holy Quran like how it has been decided on five daily prayers and other obligations (al-Khin, 1992). This means that the allotment has been decided by Allah to the heirs must not be ignored because Allah s.w.t has promised torment to those who transgressed His Law. Allah has said in Surah An- Nisa verse 14 which means:

"but those who disobey God and His Messenger and overstep His limits will be consigned by God to the fire, and there they will stay- a humiliating torment awaits them!" (Surah An-nisa' 4:14).

The issue that has been arised if the heir chooses the allotment through faraid is about the uniformity of provisions of law about this matter. This is because state constitution article 4(e) (ii) states list has put Muslims' personal rights that is Syariah law under state governance. This means faraid is subject under the enactment of respective states. Therefore, there is no act 
related to allotment through faraid drafted to make as reference. Consequently, all faraid decisions decided by judge which differs according to respective states is due to the fact that there are many books related to faraid being used as reference (Wan Abdul Halim, 2009). On the other hand, in certain circumstances, difficulty arised if this method is done if the property is immovable like land. For example, if the deceased leaves three lots of land for his three sons. According to the allotment of faraid each lot of land should be divided to his three sons. This will complicate the management on that land, as compared to if each son gets one lot of land.

The second method is allotment through consensus. There are issues arised from the allotment through faraid. Based on Dewan Dictionary, consensus means a meeting, something that is agreed, consultation and deal. The method of allotment through consensus can be defined as a deal and agreement among the members of heir to divide the property voluntarily by allotting the property. The division through consensus is done after an equal discussion among heirs before the instruction command done by the inheritance settlement officer. This command will be declared after the consensus among heirs. According to Sulong (2011), division through consensus is applicable when every heir agrees. This division is either in terms of dividing the property equally (based on certain lots) or granting heirs certain portion which is bigger like to mother or female siblings.

Next is the allotment of inheritance through waiver of rights (Takharuj). There are various ways and methods that have been done through waiver of rights, among others is withdrawal from receiving the inheritance and everyone agree or some of the heirs to the other heirs. Islamic Law gives the chance to the heirs either to accept or reject it. Takhruj method means the forfeit heirs that has been specified to accept the inheritance or not to accept the portion of that wealth. Through takhruj method, heir will withdraw and waive their right from getting the wealth without compensation requirement or through agreement. The breakdown of immovable property like land into small lots that has become less value is to be avoided (Rashid et.al, (2010), Hussain et.al, 2013, Sulong, 2011). The only reference or back up that justify inheritance to be divided through Takharuj is 'athar' that happened during the rule of Caliph Othman bin Affan r.a related to divided the inheritance to Abdul Rahman Bin Auf r.a's wife r.a (Ali \& Ahmad, 2013). Takharuj is aimed to give comfort to heirs to decide the portion of inheritance after their portion according to faraid is known. This method can dissolve dispute of ownership of heirs on a land, because they can discuss and achieve consensus through agreement on the status of the land. The application of division through this method can maintain relationship among the heirs at the same time able to control the ownership from talking on to other people's hand.

At a glance, there is no clear difference between consensus and Takharuj that is done as a chosen method to allot inheritance other than Faraid. This fact is acknowledged by Ahmad (2017) who concluded that the difference not noticeable between consensus and Takharuj in the division of inheritance in Malaysia. But, if seen in depth, consensus gives deeper meaning as compared to Takharuj. 


\section{The Mapping of Allotment of Inheritance in Setiu Terengganu Using (GIS)}

Geography Information System is known as GIS. This system is referred as a system to catch, keep, to test, manipulate, analysis and expose the data that is related to spatial which refers to the earth. Data that is analysed in this research is the data in terms of documented which is adopted from Syariah Lower Court Setiu Terengganu. The map is created for every allotment such as faraid, consensus and the waiver of nights (Takharuj) based on the data that is recorded in 2013.

\section{The Mapping of Allotment of Inheritance through Faraid In 2013}

Figure 1 shows the map of allotment of inheritance through faraid in Setiu in 2013. Red shows that there was no case registered. Yellow refers to only one case registered. While green denoted only two cases registered. Light blue shows three registered cases and dark blue refered to four registered cases.

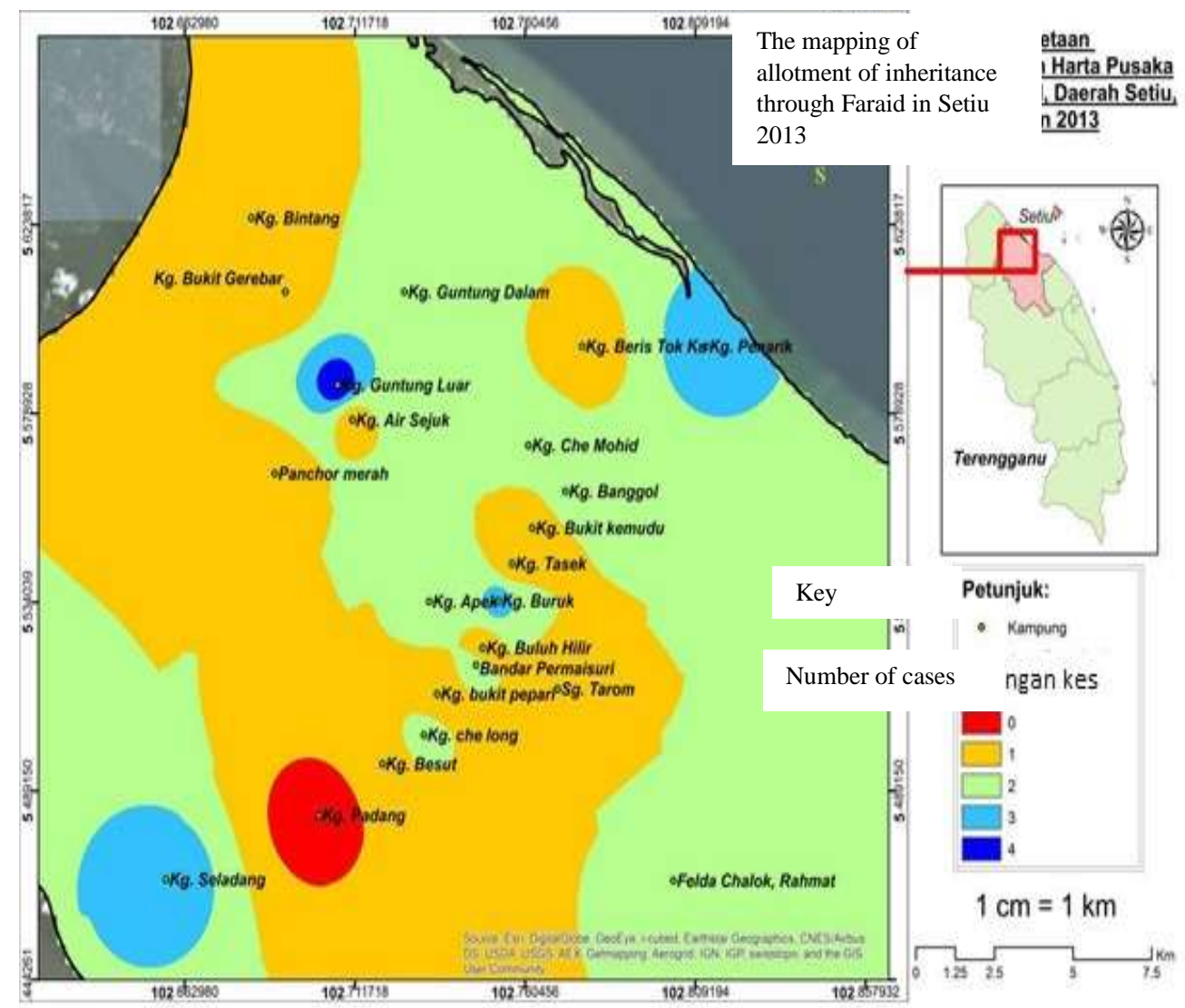

Figure 1: The mapping of the allotment of inheritance through faraid in 2013. 
Figure 2 shows overall data for the allotment of inheritence through faraid that was registered in Syariah Court Lower in 2013.

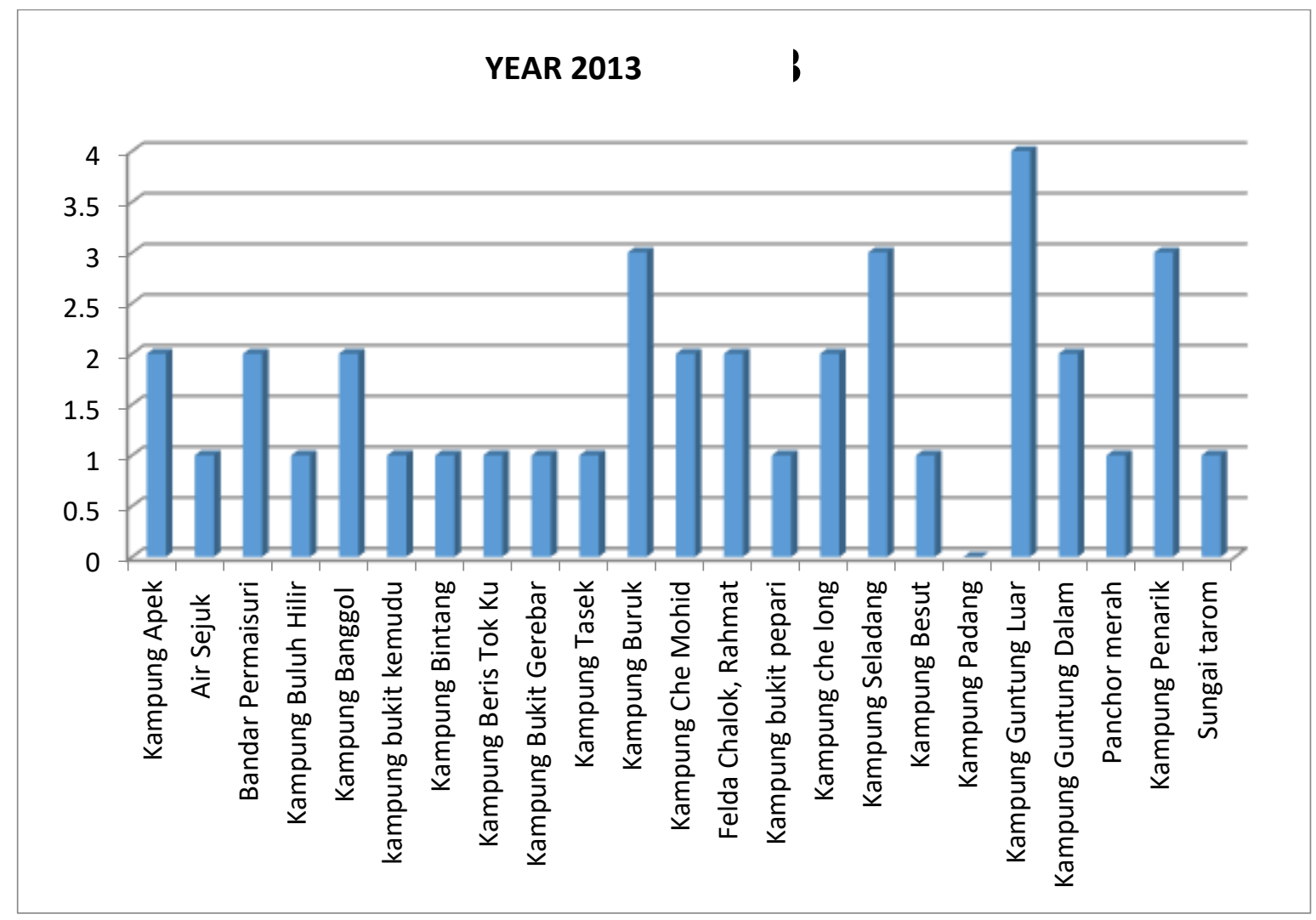

Figure 2: the number of allotment of inheritance through faraid is 2013.

The villages that recorded 1 case registered under faraid at Syariah Lower Court are Kampung Air Sejuk, Kampung Buloh Hilir, Kampung Bukit Kemudu, Kampung Bintang, Kampung Beris Tok Ku, Kampung Bukit Grebar, Kampung Tasek, Kampung Buku Pepari, Kampung Panchor Merah, Sungai Tarom.

The village that recorded 2 cases are Kampung Apek, Bandar Permaisuri, Kampung Banggol, Kampung Che Mohid, Felda Chalok Rahmat, Kampung Che Long Kampung Besut Kampung Guntung Dalam. The village that recorded 3 cases are Kampung Burok, Kampung Seladang, Kampung Penarik. Inwhile for four is Kampung Guntung Luar.

\section{Allotment of Inheritance Using Consensus in 2013}

Figure 3 shows the mapping allotment of inheritance through consensus in setiu (2013). Red shows only 1 case registered. Next dark blue shows 2 cases registered. 
INTERNATIONAL JOURNAL OF ACADEMIC RESEARCH IN BUSINESS AND SOCIAL SCIENCES Vol. 9, No. 11, November, 2019, E-ISSN: 2222-6990 @ 2019 HRMARS

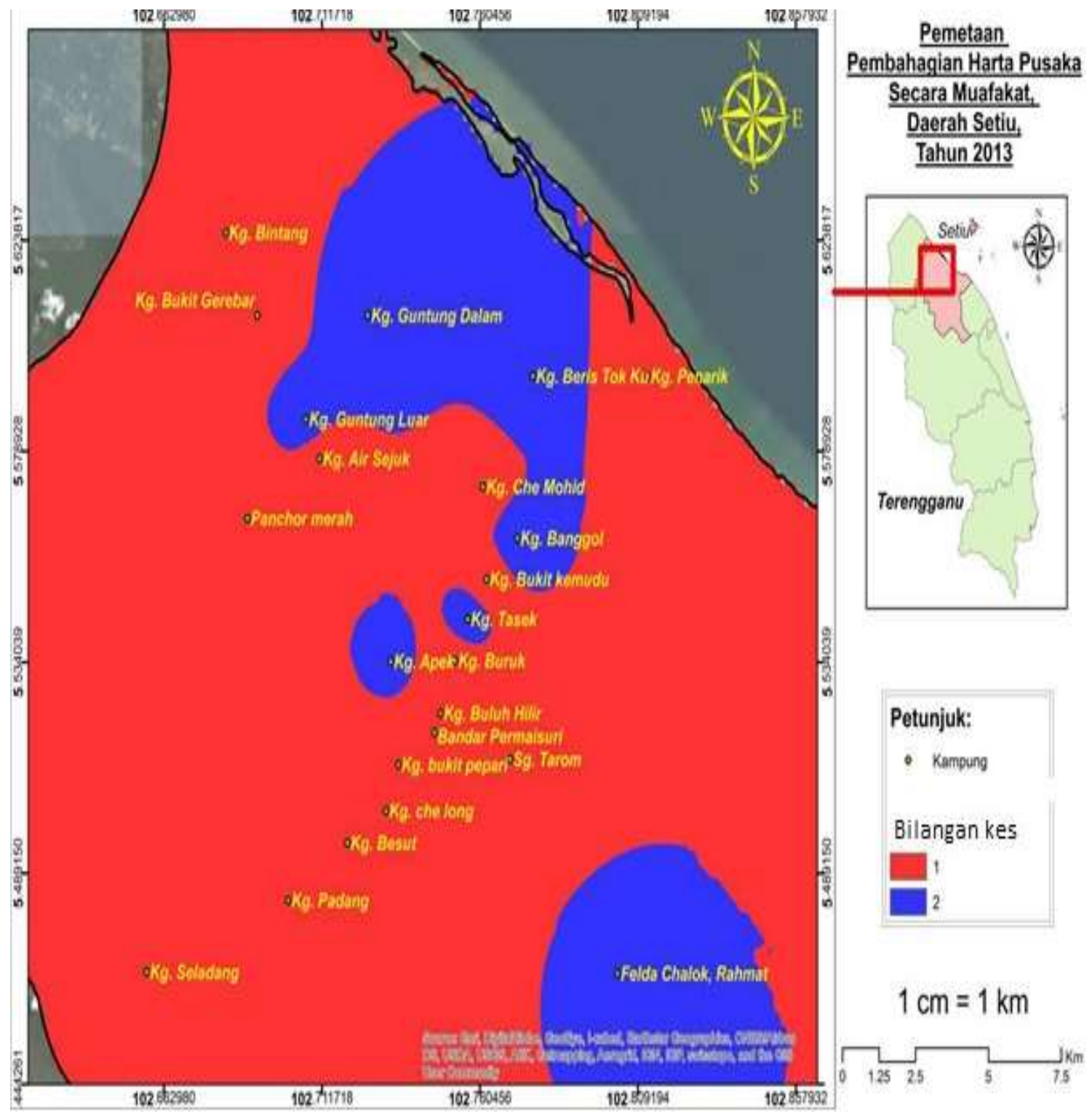

Figure 3: the mapping allotment of inheritance through consensus in 2013. 
INTERNATIONAL JOURNAL OF ACADEMIC RESEARCH IN BUSINESS AND SOCIAL SCIENCES

\section{TAHUN 2013}

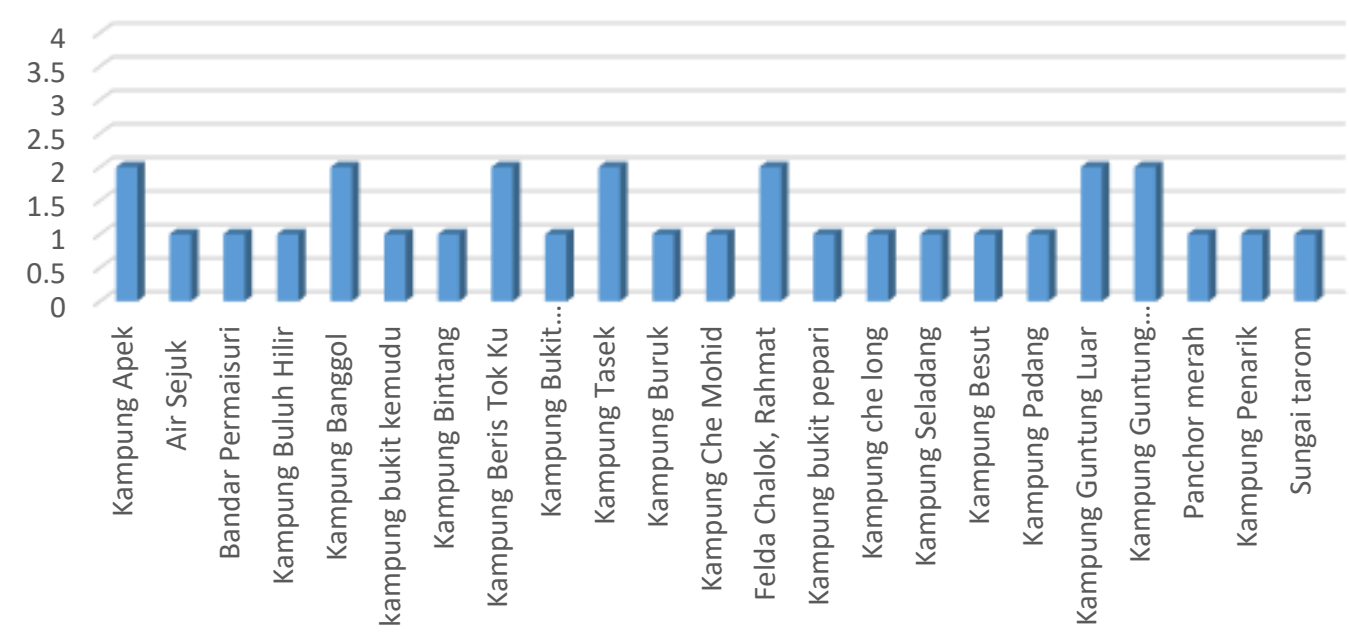

Figure 4: shows that was recorded for the allotment of inheritance through consensus in 2013.

The villages that recorded 1 case were as follows Kampung Air Sejuk, Bandar Permaisuri, Kampung Bukit Kemudu, Kampung Bintang, Kampung Bukit Drebar, Kampung Burok, Kampung Che Mohid, Kampung Bukit Pepari, Kampung Che Long, Kampung Seladang, Kampung Berut, Kampung Padang, Kampung Pachor Merah, Kampung Penarik, Sungain Tarom. The village that recorded 2 cases are, Kampung Apek, Kampung Banggol, Kampung Beris Tok Ku, Kampung Tasek, Felda Chalok Rahmat, Kampung Guntung Luar, Kampung Guntung Dalam.

\section{Allotment Inheritance through the Waiver of Rights in $\mathbf{2 0 1 3}$}

Figure 5 shows the mapping of allotment of inheritance through the waiver of rights in Setiu (2013). Red shows no case registered. Green shows only one cases while dark blue shows 2 cases recorded. The mapping will be explained in detail in the next paragraphs. 
INTERNATIONAL JOURNAL OF ACADEMIC RESEARCH IN BUSINESS AND SOCIAL SCIENCES Vol. 9, No. 11, November, 2019, E-ISSN: 2222-6990 @ 2019 HRMARS

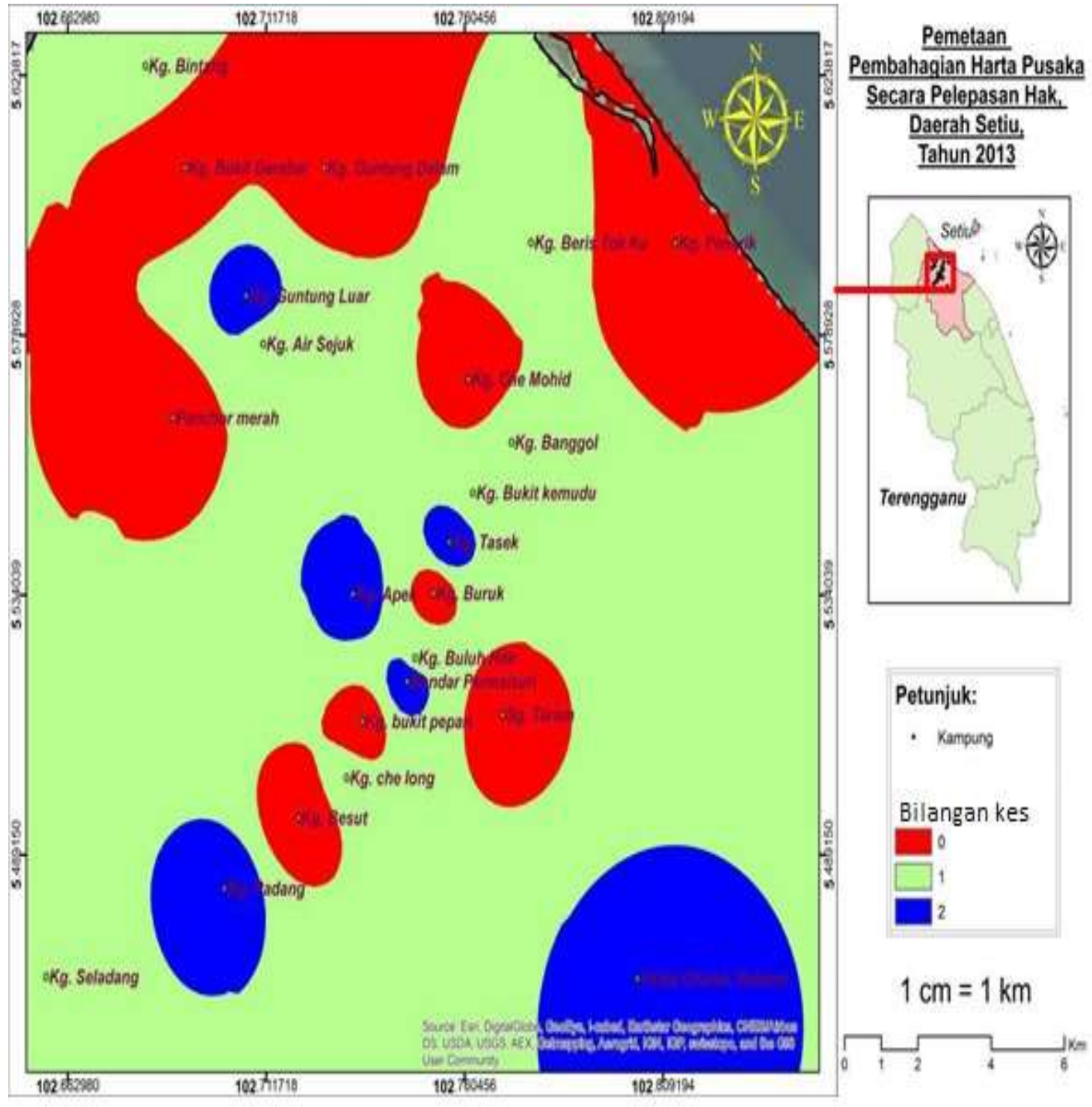

Figure 5: The Mapping of Allotment Inheritance Through The Waiver Of Rights In 2013.

Figure 6 shows data was recorded for the allotment of inheritance through the waiver of nights in 2013. 


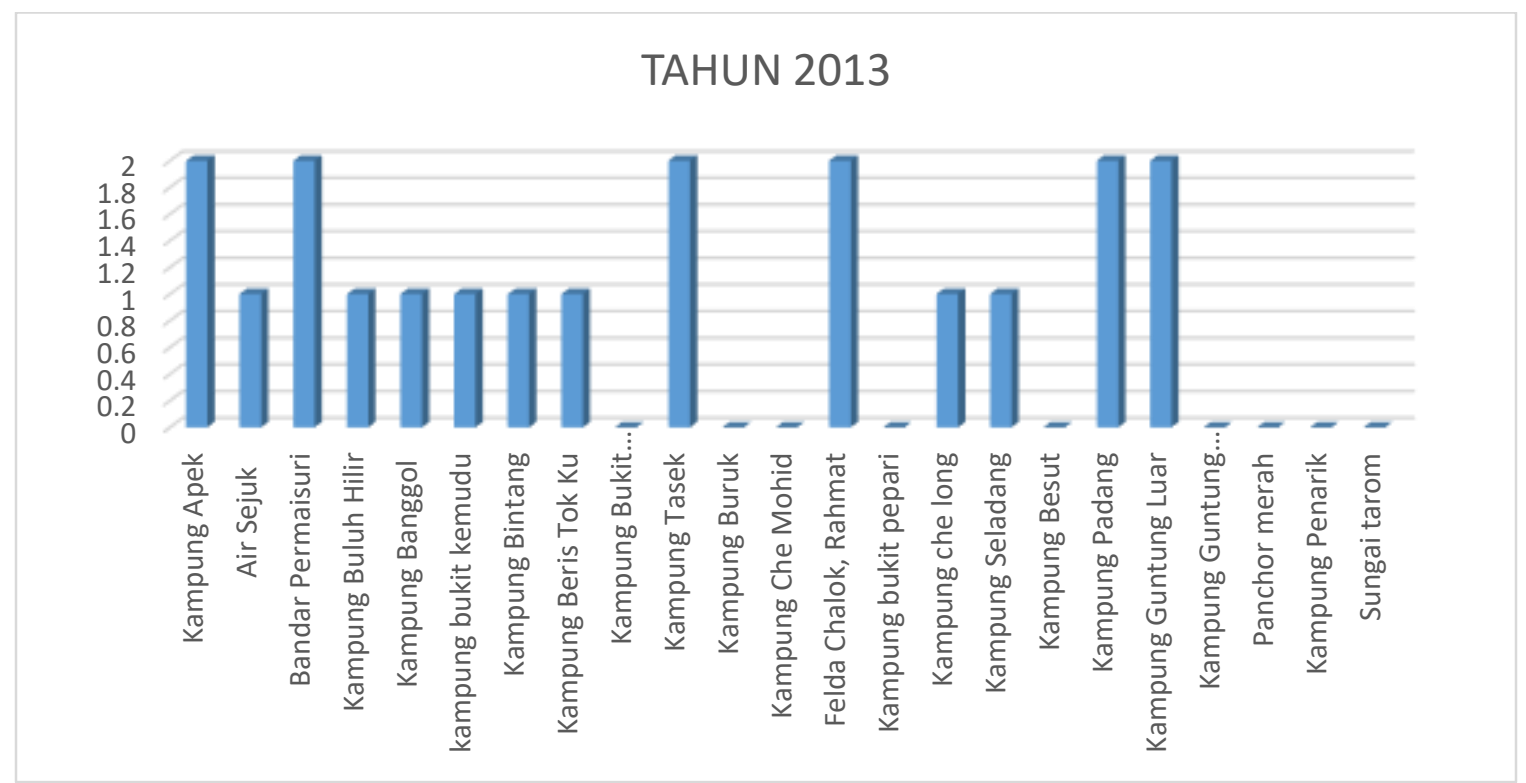

Figure 6: the number of allotment of inheritance through the waiver of rights in 2013.

The villages that recorded one cases were Kampung Air Sejuk, Kampung Buloh Hilir, Kampung Banggol, Kampung Bukit Kemudu, Kampung Bintang, Kampung Beris Tok Ku, Kampung Che Long, Kampung Seladang.The village that recorded 2 cases were Kampung Apek, Bandar Permaisuri, Kampung Tasek, Felda Chalok Rahmat, Kampung Padang, Kampung Guntong Luar. No are cord found, Kampung Bukit Berba, Kampung Burok, Kampung Che Mohib, Kampung Bukit Pepari, Kampung Besut, Kampung Guntong Dalam, Kampung Panchor Merah, Kampung Penarik And Sungai Tarom.

\section{Conclusions}

In general, this research can help Syariah Court Lower in Setiu Terengganu to upgrade its management and the implementation of the allotment of inheritance by referring to the mapping generated by GIS. The previous researches have shown that the Muslim community did not have enough knowledge about the claiming and distribution process of inheritance (Amrullah \& Salim, 2018). This was due to the fact that, the society was not given the awareness, exposure and proper procedures to claim the inheritance (Rashid \& Yaakub, 2010, Nordin et al., 2012; Nordin et.al, 2013). Therefore, the Muslim community need to be exposed with issues related to inheritance (Yusuf, 2015)

The GIS mapping in the form of figure, is able to give the overall picture about the perception, attitude and tendency of the community clearer. This is to help the Syariah Court Lower Setiu, Terengganu in specific and other departments that involve with the allotment of Muslims inheritance in general to act by giving the awareness to Muslim about the procedure of the allotment of inheritance. This in directly helps to increase the management efficiency and handle 
INTERNATIONAL JOURNAL OF ACADEMIC RESEARCH IN BUSINESS AND SOCIAL SCIENCES

Vol. 9, No. 11, November, 2019, E-ISSN: 2222-6990 @ 2019 HRMARS

any issues arised from the allotment like the issue of delaying in managing inheritance and property or wealth to be frozen.

Contributors/Acknowledgement: All authors contributed equally to the conception and design of the study. We express our deepest gratitude to Center for Research Excellence \& Incubation Management (CREIM) and Faculty of Islamic Contemporary Studies, Universiti Sultan Zainal Abidin for supporting our intellectual endeavor.

\section{Corresponding Author}

Roslan Umar, Ph.D, is Associate Professor at

Faculty of Islamic Contemporary Studies, Universiti Sultan Zainal Abidin (UniSZA), Kampus Gong Badak, 21300 Kuala Nerus. Terengganu, Malaysia.

Email: roslan@unisza.edu.my

\section{References}

Affanah, H. (2019), Tajuz Qismati Mirath bi-Taradi, muat turun di laman http://iswy.co/e11n0b (14 April 2019).

Ahmad, M. Y. (2017), Amalan Muafakat dan Aplikasi Takharuj dalam Pengagihan Pusaka menurut Perspektif Undang-undang Pusaka Islam. Jurnal Islamiyyat 39 (1): 21-28.

Al-Asqalani, I. H. (1987). Fathul al-Bari ma`a Sahih al-Bukhari. Kaherah: Dar al-Rayyan li al-turath.

Ali, W. N. W. D., Ahmad, M. Y. (2013). Mekanisme Aplikasi Takharuj dalam Pembahagian Harta Pusaka Kecil di Kuala Terengganu. Jurnal Islamiyyat 35(2): 27-33.

al-Khin, M., al-Bugha, M. D., \& al-Saariji, A. (1992). al-Fiqh al-Manhaji ala Mazhab Imam alShafi'e. Damsyik: Dar al-Qalam.

Al-Quran al-Karim.

Al-Sabuni, M. A. (1989). al-Mawarith fi al-shari 'ah al-Islamiyyah fi Daw'i al-Kitab wa al-Sunnah. Damsyik: Darul Qalam.

Al-Sharbiny, M. K. (1995). Mughni al-Muhtaj Ila Ma'rifati Ma'ani alfadh al-Minhaj. Beirut: Dar Fikr.

Amrullah, \& Salim, W. N. M. (2018). Administration of Estates in Malaysia: Determinant of Factors behind the Delay in The Distribution of The Deceased's Asset. Journal of Nusantara Studies. 3(1): 75-86.

Awang, M. R. (2008). Isu-isu Keadilan dalam Pengagihan Harta Pusaka. Bangi: Fakulti Pengajian Islam, UKM.

Azmi, F. A., \& Mohammad, M. T. S. (2011). The causes of unclaimed, late claimed or distributed estates of deceased Muslims in Malaysia. In International Conference on Sociality and Economics Development (Vol. 10, pp. 440-444). Singapore.

Harun, W. A. H. W. (2011). Mengurus Harta Pusaka. Selangor: PTS Professional.

Harun, W. A. H. W. (2006). Pengurusan dan Pembahagian Harta Pusaka. Selangor: Dawama.

Harun, W. A. H. W. (2009). Isu-isu Pembahagian Harta Orang Islam di Malaysia dalam Konteks Perundangan Malaysia. Jurnal Pengurusan JAWHAR 3(1): 159-187. 
Harun, W. A. H. W. (2011). Mengurus Harta Pusaka. Selangor: PTS Profesional Publishing Sdn. Bhd.

Hussain, N. M., \& Muhamad, N. H. N (2013). Mekanisme pembahagian harta pusaka tanah rancangan: Kajian di Felda Taib Andak, Kulai Johor. Kanun, 25(1): 1-10.

Imam, T., Ali, H., Soo, H.S. (2018). Dilemma of Employee Retention through the Lens of Organizational Politics: A Quantitative Study on Pharmaceutical Industry of Pakistan, International Journal of Academic Research in Accounting, Finance and Management Sciences 8 (3): 26-36.

Noordin, N., Shuib, A., Zainol, M. S. \& Adil, M. A. (2013). Delay in Islamic Inheritance Claim - An Ignorance Issue. Procedia - Social and Behavioral Sciences. 90: 504-512.

Noordin, N., Shuib, A., Zainol, M. S., \& Adil, M. A. (2012). Review On Issues And Challenges In Islamic Inheritance Distribution In Malaysia. OIDA International Journal of Sustainable Development. 3: 27-38.

Rashid, R. A., \& Yaakub, N. I. (2010). Masalah kegagalan dan kelewatan pengagihan harta pusaka di Malaysia. Jurnal Intelek 5(2): 1-18.

Sulong, J. (2011). Pembaharuan Undang-undang Pentadbiran Pusaka Islam. Pulau Pinang: Penerbit Universiti Sains Malaysia.

Yahya, H., Razali, A. B., \& Baki, R. (2018). To Tell or Not to Tell: Exploring Malaysian Teachers' Perceptions towards Storytelling in English Classrooms. International Journal of Academic Research in Progressive Education and Development, 7(4), 303-323.

Yusuf, M. A. M. (2015). Institusi Pendidikan Islam dan Fungsinya Sebagai Sumber Pengetahuan Ilmu Faraid dalam Kalangan Masyarakat Islam di Pulau Duyong, Terengganu. Jurnal Islam dan Masyarakat Kontemporari. 10: 49-67. 